\title{
計画的戸建住宅地における専有空間の緑の管理による
} 街なみ形成態度とその規定要因

\section{STUDY ON DEVISING IMPROVEMENT OF LANDSCAPING THROUGH MANAGEMENT OF GREEN AREAS OF PRIVATE SPACES IN PLANNED DETACHED HOUSING AREA}

\author{
齊藤広子* \\ Hiroko SAITO
}

\begin{abstract}
The purpose of this study is examine how to develop greens at private spaces at the period of housing supply and manage them to formulate better landscape in a planned detached housing area. For this end, the study mainly clarified the following points through questionnaire survey to residents and field investigation survey. 1) By housing supply with hedge, harmonized and totally coordinated landscape are formulated, residents highly satisfyit. 2) A Planting Agreement is an effective tool for continuous maintenance of greens and trees appropriately. 3) The harmonized landscaping with greens and trees, which were provided for the residents, significantly contributes to rise the residents' motivation, and facilitate them maintain landscape well.
\end{abstract}

Keywords: Planned Detached Housing Area, Green, Management, Landscape 計画的戸建て住宅地管理街なみ

\section{1. 研究の背景・目的}

\section{・計画的戸建て住宅地の绿の整備功向と問庭意㼄}

計画的戸建て住宅地において、公園や道路といった公有空間につ いては従来から緑が整備され供給されていたが、最近では街なみや 景観・住濖境を考慮した計画的戸建住宅地が增え、共有空間をとり、 そこに緑を整借したり、專有空間についても緑を整備し供給するこ とが多くなっているい。

公有空間の緑とは保存緑地、緑地・公園、緑道、街路樹など、共 有空間のとはコモンスペースの樹木・植栽、コモン緑地など、尃 有空間の緑とは生垣、庭木などである。

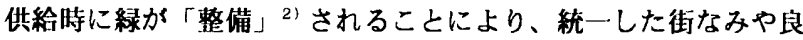
好な景観が生み出されることになるが、その後の管理が良好に行わ れないと、供給当初の街なみが崩れ ${ }^{3)}$ 、住環境の悪化にもつなが ことがある。このように緑が良好に管理されないのは、管理をする 主体者が整備過程に関与していない、つまり管理主体者と整備主体 者が異なるからと考えられる。

公有空間の緑は必ずしも整備主体者之管理主体者が一致している わけではないか、開発事業者が整備主体者である場合でも管理主体 者となる行政の関与が整借過程にある。しかし共有空間及び専有空 間の緑が供給前に整備される場合はその整備過程に所有・管理主体

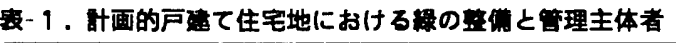

\begin{tabular}{|c|c|c|c|c|}
\hline \multirow{2}{*}{ 空間 } & \multicolumn{2}{|c|}{ 整 備 } & \multirow[t]{2}{*}{ 所 有 } & \multirow{2}{*}{ 管 理 } \\
\hline & 計 画 & 植 樹 & & \\
\hline 公有空間 2 & $\begin{array}{c}\text { 行政 } \\
\text { 開発事業者 }\end{array}$ & \begin{tabular}{|c|} 
行 政 \\
開発事業者
\end{tabular} & $\begin{array}{l}\text { 行政 } \\
\text { 行政 }\end{array}$ & $\begin{array}{l}\text { 行政 } \\
\text { 行 政 }\end{array}$ \\
\hline 共有空間 & 開発事業者 & 開発事業者 & 居住者共有 & 居住者共同 \\
\hline 専有空間 ${ }^{33}$ & 開発事業著 & 開発事業者 & 居隹者 & 腒住者 \\
\hline
\end{tabular}

1)管理方法を考察することからその第一義的責任者となる所有者に注 目し空間を分類する。

2)下段の場合でも基準の㯏定や指導等で整備過程に行政の関与がある。 、段は供給後に居住整が借が行われる楊合である。

者となる居住者の関与はほとんどみられない4)のである（表一１）。 そのため、街なみ形成を考虑して整備された共有空間・専有空間 の緑が居住者にどのように評価され、整備意図通りに良好に管理さ れ、本当に街なみ形成に笴与しているのであろうかという疑問がで てくる。緑による街なみ形成を考えていくには、上記の疑閣に答え ると共に、さらには緑を良好に管理し、街なみ形成を行っていくた めに整備方法だけでなく、管理方法も共に考えていくことが必要で ある。どのような管理方法を設定すればよいか、この点を考慮する ことも必要である。

緑の管理については公有空間、共有空間と専有空間では所有・管 
理主体者が異なることから、刘象を専有空脂に腿定し、考察する。

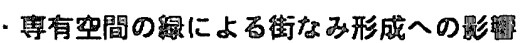

専有空間の粶のなかで街なみに最も影翠を与えているのは外構部 分である。外構部分を生垣にすることにより、街なみ形成を図ると いうことがある。そこで緑による街なみ形成を罒るには、第一に外 構を生垣にすることがある。第二には、その生垣を良好に管理する ことである。つまり、専有空間の緑による街なみ形成は「外構の状 態一生垣にすること」「その生垣を良好に管理すること」により渋 成されることになる。この .つちどのようにすれば推し進めていけ るのかを考察することが本研究の課題である。

\section{関連既往研究之本研究の位置付け}

専有空間の粶による街なみ形成は「供給時の整㣁方法；と「管理 方法」により大きく規定される。既往研究では管理方法の一つよし て緑地協定や建築協定を滴結することにより、生垣化が促進され、 良好な管理にも寄与することが明らかにされている5゙。

管理方法としてこういった -つのルールを示すことにより街なみ に影敖を与える居住者の熊度を「規制」するという方法もあるか、、 緑によりもっとよい街なみにしていきたいという居住者の気持ちを 促進し、その実晛をスムースに「誘導;することが、もう一つの方 法として考えられる。そのためには居住者が街なみについての目䧣 のイメージを共有し、その手段を共有するといった共有化がある。 目標のイタージの共有化には、管理方法として街なみのあるべき 姿を示すための「ガイドラインの作成」があり、手段の共有化には 「植栽組合の結成」「生堛の共同管理」の実路などがある。しかし このような実践は現状では少ない。

現状のなかでは緑による街なみ形成に最も勃果があるのは「今あ る緑による街なみを守りたい．もっと良くしたい: という居作者の モチベーションを高めていくことではないだろうか。建策協定や緑 地協定といったルールも、すでに良好な街なみが形成されている場 合に「それを守りたい!という居住者の意讙があるもとでは現在の 街なみを担保する手法として行效に賦くものと考えられる。

そこで、本研究では低給时にどのように専有㠫間の緑を整備すれ ば居住者は街なみに寄与する熊度となるのか、つまりどうすれば居 住者は外構を生垣にするなど緑を促進し、それを良好に管理するこ とが促進されるのかを明らかにし、それに緑地拹定などの規制を前 提としたルールがどのように有効に颠くのかを明らかにする。

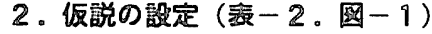

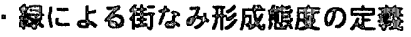

専有空間の緑のなかで街なみ形成に寄与するものとして:五に外構 に注目し、外抟を生垣にし、それを良好に管理する居住者の態度を 「緑による街なみ形成熊度」と定羲する。それは「緑の整㣁態度」 「緑の管理態度」により輤成される。なお、態度には行動的成分と 諗知的成分がある。

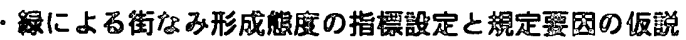

(1)「緑の整備熊度」の行動的成分を示すものとして「緑の整備状態 (外構の状態)をとりあげる。外構の状態は供給当初の整備方法及 び管理方法として緑のルール（協定など）の存在により界なるあ。 (2)「緑の管理態度」の行動的成分を示すむのとして「緑を良好に管 理しているか、さらに皱化を推進し、街なるに寄与する態度であ
るのか（管理の状態）」をとりあげる。そこで管理の状態として 「生坦の手入れ」と「門まわりの緑化推進・表出」を指標として とりあげる。

(3)粶の管理の状態は、署.居住者の街なみ謤価 圆.居住者が各家の緑 の管理を負担に思うかどうか、圈、緑の管理方法があるかどうか、 居住者はその管理方法により規制や誘導されることになる7が、 基本的にはその管理方法をどのように䛇知・評価しているのかに より異なる。さらに居住者の绿の管理態度、は、固.居住者が共同 で管理をしようとするコミュニティ形成の状態によっても異なる。 圈.居住者の街なみ評価は粶の整備状熊により異なる。粶について の率価や满足は単絰に粶の聂だけでなく、質によっても異なる 8)。居住者の街なみ語価は各住宅 (専有空間) の緑の整備状熊よ りもむしろ住宅地全体としてみた専有空間の緑の擎備状態に規 定される。

圆.绿の管理の負担尉は、外構が生垣か否かといった緑の整備状態、 現在の街なみをどのように思うのかという街なみ謤価、管理方 法とその諗知や俨洒、コミュニティの状熊（例えば、近陆と仲 が良いなど)により異なる9!

圈.绿の管理方法として、翡の整備・管理のルールの有無とそれを 㕆住者がどのように認知し、俨価しているかをみる。

留.ユミュニティ形成としては、近擶つきあいをみる。専有空間の 管理の場合、住宅地全体として居住者が共同で取組むよりも各 自で取組むことが多く、そのためコミュニティとしては近蹅と の助けあいや手入れをしないことによる近隐に迷感をかけるこ とへの配虑など、陮近所との関係やつきあいにより影響がでる。

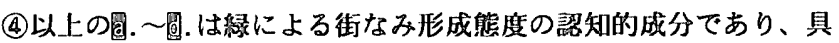
体的には行動的成分を規定するものとなる。

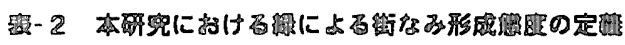

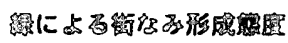

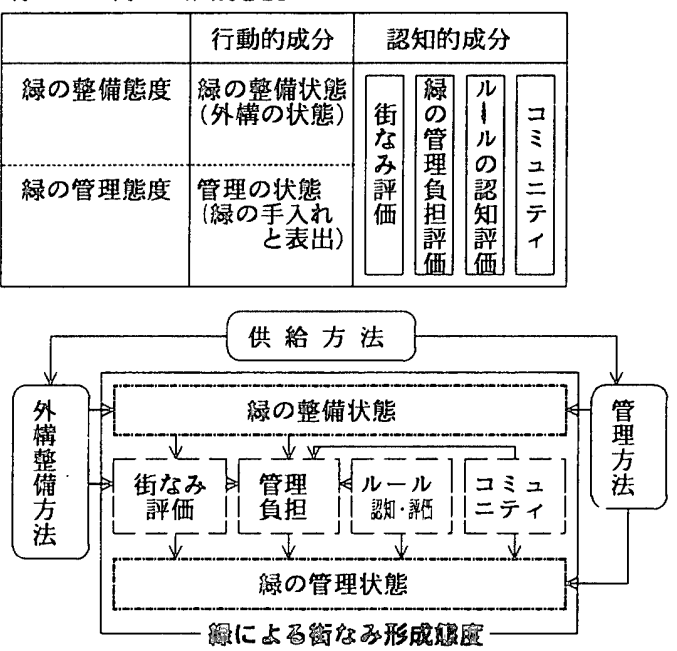

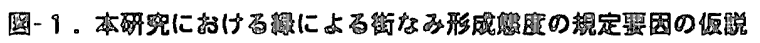

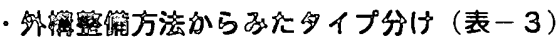

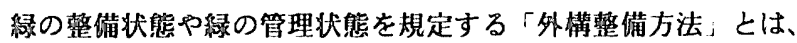
供給時に粶が澁備されているか否か、整備されている埸合にはその

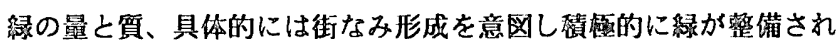
たか否かである。外構整備タイブとして、「供給時の緑整備の有無

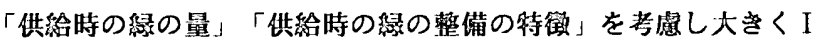




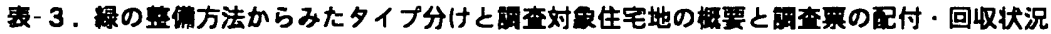

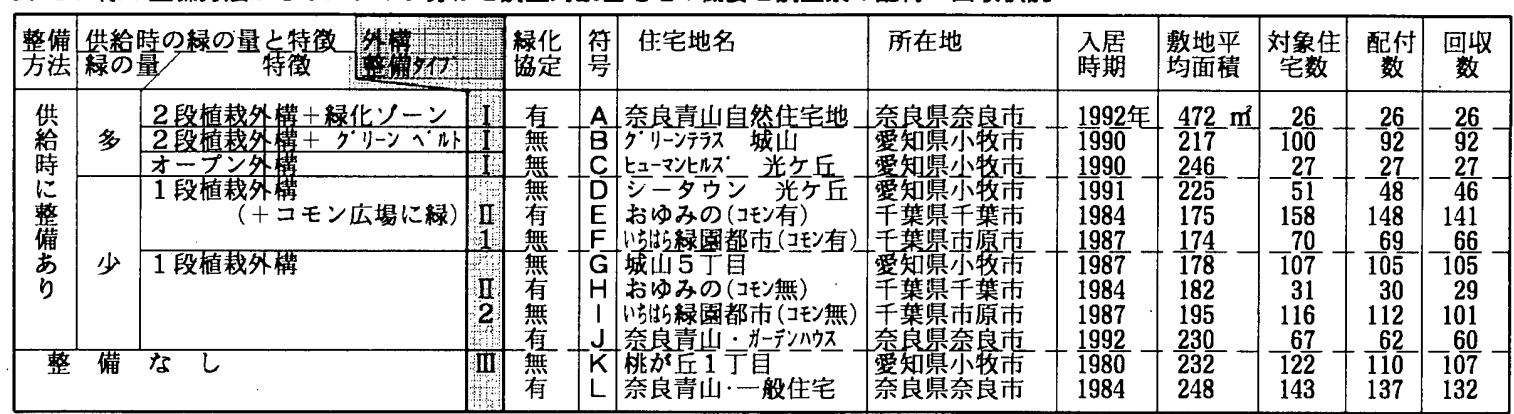

* II-1とII-2はコモン広場の有無が異なるが、専有空間の整備方法には相違がないため、【タイブとした。

* I〜IIのタイブは全て供給時に庭夺として数本植街されている。

* AとJ とL，BとCとDとGとK， EとH，FとIはそれそれ同じニュータウン内にある。

〜IIIのタイプに分類した。

タイプI は供給時に開発事業者により綵の整備が行われたタイプ のうち、緑の量も多く、街なみ形成を意図し積樰的に証備された夕 イプである(0)。そのなかで特徵的なものとして、2 段植栽外構に し道路境界線より $2 \mathrm{~m}$ の緑化ゾーンを設けているタイプ（A住宅地

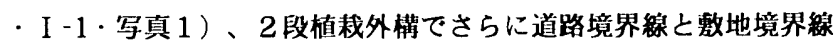
の間に幅 $1 \mathrm{~m}$ のグリンベルトを設けているタイプ（B住宅地・I 2・写真 2)、門や塀を設けずオープン外構にしているタイプ（C 住宅地・I -3・写真 3) などがある。

タイプПは供給時に開発事業者により緑の整備が行われたタイプ のうち、1 段植栽外構の整備之数本の植栽の植樹が行われたタイプ (写真4) であり、あまり積極的に外構整備したものではない。 タイプIII (写真 5) は供給時に外棈の整備がなかった住宅地である。
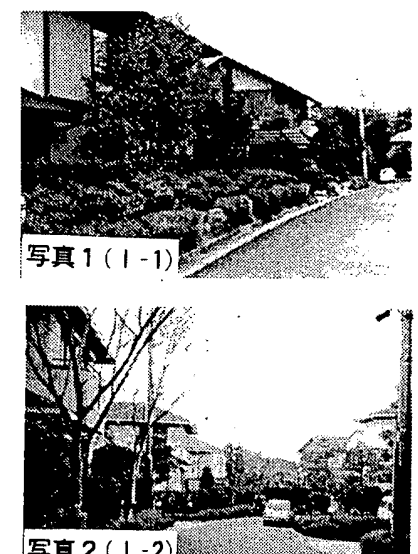

写冝 $2(1-2)$
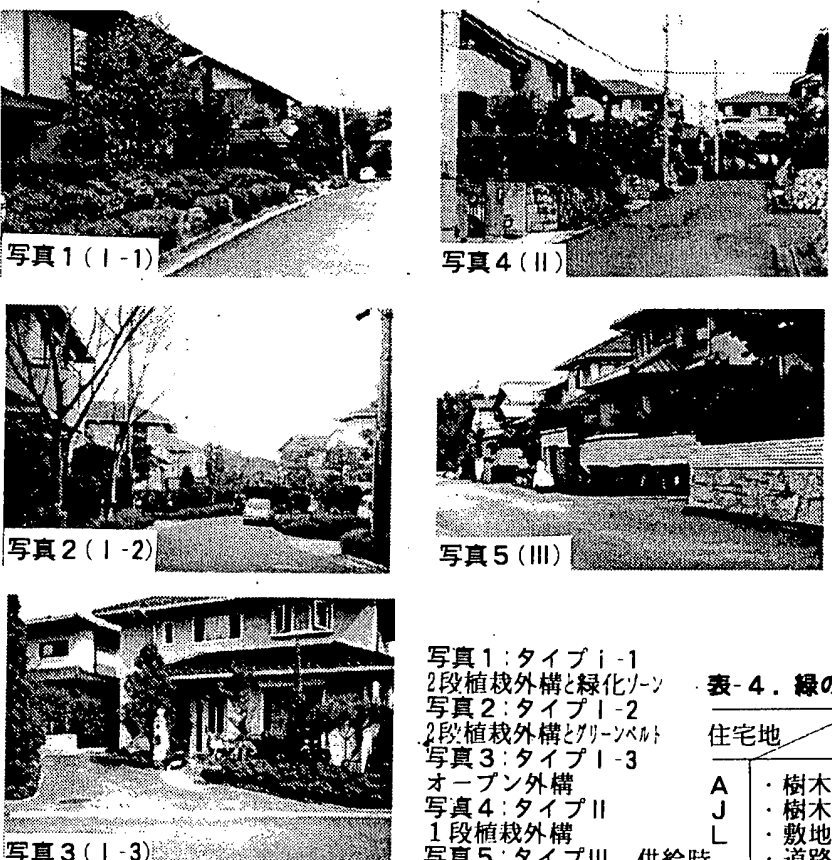

写真 $1:$ タイプi -1

段植栈外構(粶化\%

写宾 $2:$ タイプ|-2

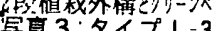

オープン外構

写兾 $4:$ : タイプ

写寅 $4:$ 多プ

写段植䉽外構 写寡 $5:$ タイプIII 供給時 外構整備のない住宅地

\section{3. 研究の方法}

調查対象住宅地の䕉定と概要（表－3）

外模整備方法及びルールの有無による居位者の街 なみ形成熊度の相違をみるために、淕查対象住宅地 の選定は、外構整備タイプ I 〜III住宅地が含まれ、 かつ緑の管理方法としては緑の整備・管理ルールと して緑地協定の有無を考慮した。さらに、入居開始 よりあまり年数が建っていないものは外構などの緑
の整備状熊の変更が少なく、管理の状態の違いもみられにくいこと から、入居開始より 5 年以上が経過している住宅地とした。その結 果、同じニュータウン内にあり外構整備タイブが異なる住宅地でほ ぼ同じ時期に入居開始が始まった地区が含まれるように選定した。

\section{・調查の方法}

上記に示した仮説を検証するために居住者アンケート調査と外部 観察謂㚗を実施した。

調直対象住宅地の居住者を対象に、緑による街なみ形成熊度を把 握するためのアンケート語榃を1996年 9 月〜1997年12月に淔接訲問 配付・留置自記入後、直接訪問回収する方法で奏施した。調查対象 住宅数合計1018、配付数966、回収数939、回収率は97.2\%である。

緑の整備・管理状熊を把握するために調查対象住宅について外部 観察調查を1997年 9〜12月に実施した。

\section{4. 謂查対象住宅地の緑の整備・管理ルール（表一 4)}

$\mathrm{A} \cdot \mathrm{J} \cdot \mathrm{L}$ 住宅地は風致地区にあり、その環境を守るために緑化 協定"11 が開発事業者により締結された。さらにA住宅地のみ、緑 化ソーンが建築協定で設定されている。

$\mathrm{E} \cdot \mathrm{H}$ 住宅地でも同様に緑化協定が開発事業者により蟐結されて いる。共に「樹木の種類」や「良好な維持管理」が規定されている。 F · I 住宅地は緑化協定はないが、いわゆる一人協定の建築協定 で称の整備・管理のルールとして、「灌道緑地」か規定されている。

$\mathrm{B} \cdot \mathrm{C} \cdot \mathrm{D} \cdot \mathrm{G}$ 住宅地もいわゆる一人㶸定の建策協定で抽象的で はあるが緑化推進」が規定されている。

K住宅地はB・C・D・G住宅地と同じニュータウンにあるか、 建筑協定が期限切れになり失效し、現在は緑の整備・管理に関する ルールは規定されていない。

\begin{tabular}{|c|c|c|}
\hline \multicolumn{2}{|c|}{ 住宅地 ルールの内容 } & \multirow{2}{*}{\begin{tabular}{|l} 
㙝定名 \\
緑货 \\
定 \\
建築協定
\end{tabular}} \\
\hline & 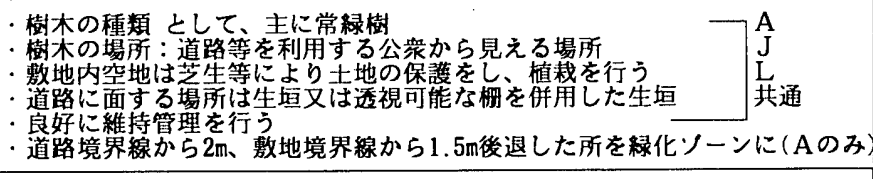 & \\
\hline $\mathrm{E}$ & 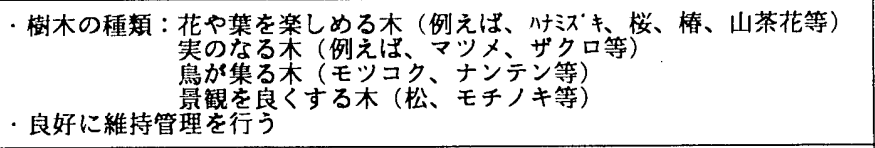 & $\begin{array}{l}\text { 督华 } \\
\text { 定 }\end{array}$ \\
\hline $\mathrm{F}$ & $\begin{array}{l}\text { ·宅地の道路境界線側に幅 } 50 \mathrm{~cm} \text { の沿道緑地を設け、緑化に努める } \\
\end{array}$ & 建築 \\
\hline $\begin{array}{l}B, C \\
D, G\end{array}$ & $\begin{array}{l}\text { ·宅地内の空地は椂化に妢める } \\
\text { ·外構は生垣、又禖なフェンス、佣等 } \\
\end{array}$ & 建築 \\
\hline $\mathrm{K}$ & な & - \\
\hline
\end{tabular}




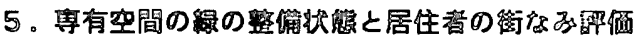

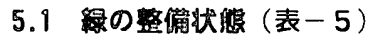

各専有空間の龁の整備状熊を「外構の状態」からみる121。

外構に関しては、供給時に外楧整備が行われた場合は供給時のま まの「生垣」が多い。しかし、入居後居住者が生垣よりも道路側又 は住宅側にフェンスや相を設ける場合（表一5の「性等：や）やフ ロック塌など（表一5の「その他!）にかえることがある。それら

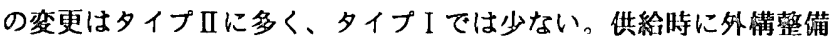
が行われていない場合（タイプIII）でも「生望」が鼠も多いが、

「生垣等」や「その他」の比率が高い。

緑化協定の有無による外構整備状熊の相違をみる。I ・II タイブ では見在の外構の状態は供給時の整備状態の億摖が大きいことから、 協定の有無による外構整備の犾態の相違をみるには適切ではない。 そこで供給時に粶が整備されていなかったIIIタイプに限定してみる

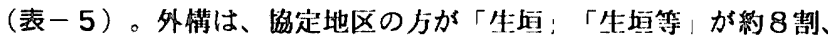

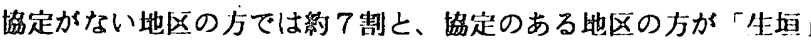
などの比率が高い。

しかし、外構の状熊は㙝定の有無よりも间じ湓定がありながら整 備方法が巽河ることによる違いのおが大きい（图一2）。具体的に

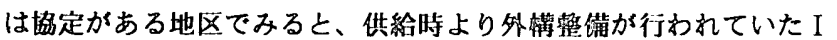
Iタタプではすべて「生垣」または「生㻥等」であるか、供給時に

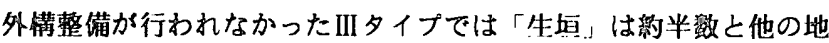
区に此へて少なく、「生垣」と「生垣等：を併せても約８割と他の 地区に比べて低い。

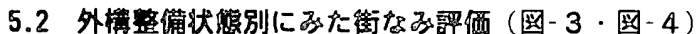

供給時の外構整借方法に対する居住者の謤洒之外满整借方法によ り居住者の街なみ評価が゙のように巽なるかをみるい。

タイプIはそれぞれ外構整備に特征をもっているか、それぞれの 特徵についての謤価をみると、A住宅地（タイプI-1）では「緑化 ソーンを設定」し、「2段䡩载外構」になっており、それぞれにつ いて居住者の7割以上の人が大变良い」または「良い,之俨偠し ている。B住宅地（タイブ I -2）の「グリーンベルト」については その住宅地の約 9 制の人が、C住宅地（タイプI-3）の「オープン

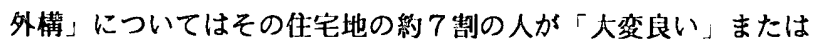

「良い」と俨洒している。

次に各住宅地の外構についての居住者の謤洒をみると、供給時に

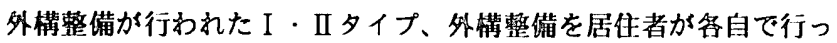
たIIIイプのなかで、居住者の評価はIタイプで高い（圆一3）。

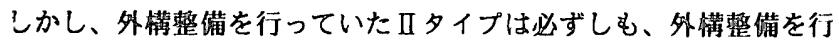
っていなかったIIIタイプより評価が高いわけではない。

次に、街なみの評価をみると、自分の家の外棈が「生垭。である 場合も「その他」である場合も、居住者の街なみ俨価に大きな相違 はない（図一）。

住宅地別にみる上、供給時に緑の整備が行われた住宅地で必ずし む街なみ䛨価が高いわけではない:タイプにより異なっており、特

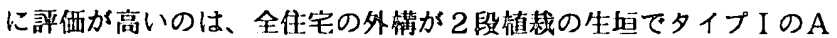
住宅地（I -1）である。供給時に緑が整備された住宅地のなかで、 琵楆的に緑による街なみ形成を意龱し整備されたタイプIの評価は 全体的に高い。

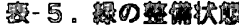

渌の整備・管理方法別にみた外满·木の量の構成率（\%)

\begin{tabular}{|c|c|c|c|c|c|c|c|}
\hline & & & & 末の & (高榃 & 下.中查 & :本 \\
\hline 備·管理方 & 生垣 & 生垣 & その他 & $\sim 5$ & $\sim 1$ & $\sim 20$ & $21-$ \\
\hline 右E & $\begin{array}{l}77.6 \\
42.7 \\
\end{array}$ & $\begin{array}{r}11.9 \\
28.7 \\
\end{array}$ & $\begin{array}{l}10.4 \\
28.6\end{array}$ & $\begin{array}{l}65.0 \\
40.4 \\
\end{array}$ & $\begin{array}{l}26.0 \\
33.2 \\
\end{array}$ & $\begin{array}{r}6.7 \\
22.4 \\
\end{array}$ & \\
\hline $\begin{array}{l}\text { I }-1 \\
I-2 \\
\text { I }-3 \\
\text { II }-1 \\
\text { II }-2 \\
\text { II }-\end{array}$ & $\begin{array}{r}100.0 \\
90.0 \\
96.3 \\
73.7 \\
75.8 \\
42.7\end{array}$ & $\begin{array}{r}0.0 \\
7.0 \\
3.7 \\
9.0 \\
17.6 \\
28.6\end{array}$ & $\begin{array}{r}0.0 \\
3.0 \\
0.0 \\
17.3 \\
6.6 \\
28.6\end{array}$ & $\begin{array}{r}0.0 \\
56.0 \\
59.3 \\
70.3 \\
69.2 \\
40.4\end{array}$ & $\begin{array}{l}33.0 \\
25.9 \\
24.4 \\
26.6 \\
33.2\end{array}$ & $\begin{array}{r}34.6 \\
11.0 \\
14.8 \\
4.9 \\
3.9 \\
22.4\end{array}$ & 4 \\
\hline 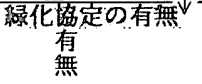 & 52 & $\begin{array}{l}25 \\
31\end{array}$ & $\begin{array}{l}22.4 \\
33.6\end{array}$ & $\begin{array}{l}54 \\
30\end{array}$ & $\begin{array}{l}32 \\
33\end{array}$ & 29.4 & \\
\hline
\end{tabular}

外槽

生唔等 : 生垣とその内又は外側にフェンスや棚が設置されている その他 : 生垣はなく、フロック娒や柵のみ等

本の量は街なるへの影留の大きさを考慮し、高木と中木に限定し、

㭼の管理・手入れの因難性を考慮し、高木と中木を次の上うに定

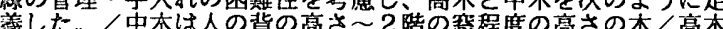

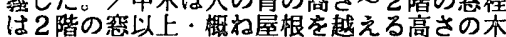

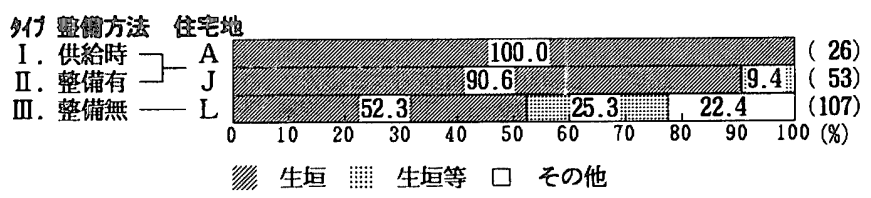

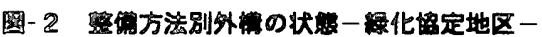

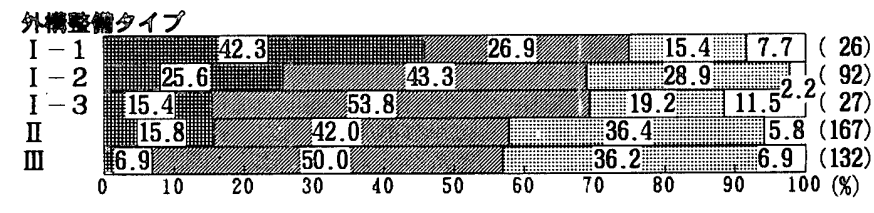

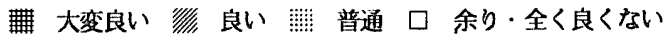

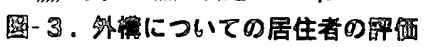

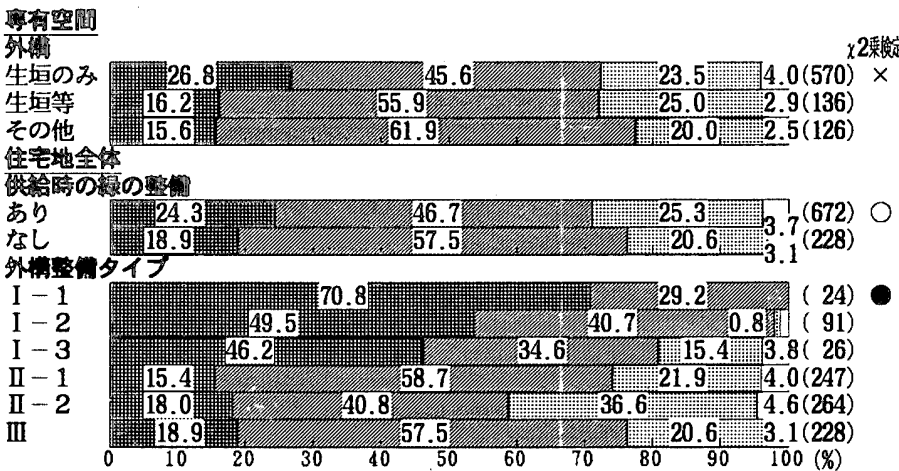

带大变良い

$\chi 2$ 乗检定に色険率 $0.5 \%$ で有意な差加見られるもの、危険率1.0\%は、5.0\%は 10.0\%は $\triangle$ 、危険率10.0\%でも有意な差が見られないもの

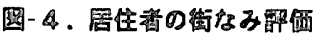

このように居住者の街なみの評価は各専有空間の外構整備状態に より規定されているのではなく、むしろ住宅地全体の外構整備状管、

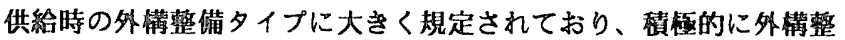
備を行って供給した住宅地では居住者の評価が高い。

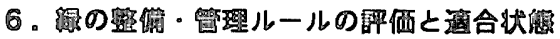

緑の整備状態も街なみに大きく影翌を与えているが、緑の管理状

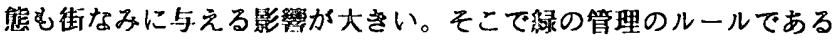
緑化協定がどのように管理狱態に影響を与えるのか、具体的には緑 化協定で規定されている内容に居住者は適合した態度となっている か、居住者の協定の評価を明らかにし、劦定内容の適合状態をみる。 
緑化協定がある住宅地では約 8割の人が拹定を「良い」と評価し、 街なみ評価の高いタイプI（A住宅地）では入居後特に評価が上が っている(図-5)。

妿定の内容についての評価は、同じ内容であっても住宅地により 居住者の評価が異なる（表一6）。樹木の種類や場所が決まってい ることは、供給時に緑の整備がなかったため自分で植樹したタイプ III（L住宅地）で「厳しい」と回答する人が約 3割之、他のタイブ に此へて多い。しかし、協定に不適合な住宅はない。緑による保詜 の規定については「䈌しい」. と回答する人がタイプIIIIII（J・L 住宅地）では約 2 割おり、タイプI に比へて多く、不適合率もタイ プIに比へて高い。外構を生垣にすることはタイプП（ $\mathrm{J}$ 住宅地） で「整しい」と回答する人が多いが、タイプIでは外構が生垣に整 備されて供給されたため、それを変更している人はおらず、不適合 率は低い。不適合率は外構が生垣に整備されて供給されなかったタ イプIIIで高い。全体的にタイプIではルールを笅しいと感じる人も 少なく、適合率が高い。

協定を「䈌しいと感じても居住者は協定があればできるだけその 内容に適合しょうとし、その意向は街なみ評価の高い住宅地でみら れる。そのため街なみ評価の高いところでは協定の評価も高く（図 -5)、協定の評価の高いところでは協定の適合率も高い(図－6)。

\section{7. 绿の管理の状雭}

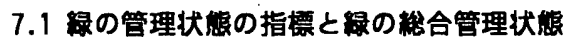

緑の管理状熊を示す指標とし14!、一つは「緑の手入れ」として 生垣を主とし、木の手入れ、下草の手入れが行き届いているか、も う一つは門まわりなどにプランター等を設置し、「緑の表出」によ り街なみを形成しようとしているかをみる（写真 6～10）。さらに この二つの項目の評価を総合し、緑の総合管理状態を設定した ${ }^{15)}$ 。

どのような場合に緑の手入れが行き届き、緑の表出が多いのかを みる（表一7、図-7）。

外構が生垣である場合、さらに各家の庭木が多い場合は共に緑は 多いか、総合管理状㙰は良い。

供給時の外構整備タイプでみる之、供給時に整備した場合に必ず しも管理が良いわけではないが、街なみ評価の高い、タイプ I の住 宅地では絰合管理状熊が良い。

緑の管理のルールとして緑化協定があると、秷合管理状態が良い というわけではない。しかし表ー7での印のある住宅地に限定して みると、㙝定がある場合には、街なみ評価の高くないII -2・IIIタイ プで緑の表出が多くなり、協定は居住者の緑の管理意識 啓蒙に寄与している。更に協定がある場合に限定し緑化 協定の詔知・評価別にみると、緑化協定を認知・評価し ている人の方が総合管理状態はやや良い。コミュニティ 形成の指標として、こ近所つきあいの状態別にみると、 近腾と視しくつきあっている人の方が近陵と街なみへの 眍虑が高まり、総合管理状態が良い。また、緑の管理を 負担と感じていない人の方が総合管理状熊がやや良い。

\section{2 粶の管理負担の評価とその規定要因（図一 8)}

居住者が緑の管理（手入れなど）をどのように感じて いるのか、負担に感じているのか否かにより総合管理の

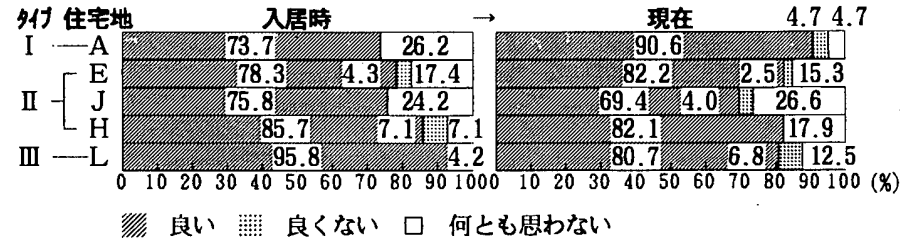

图-5化咕定に関す破価 一入居時と现在一

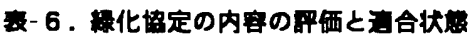

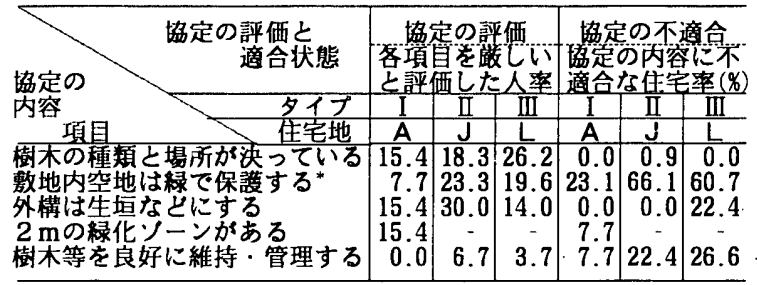

* 庭を芝生で覆っていない住宅を不適合とした
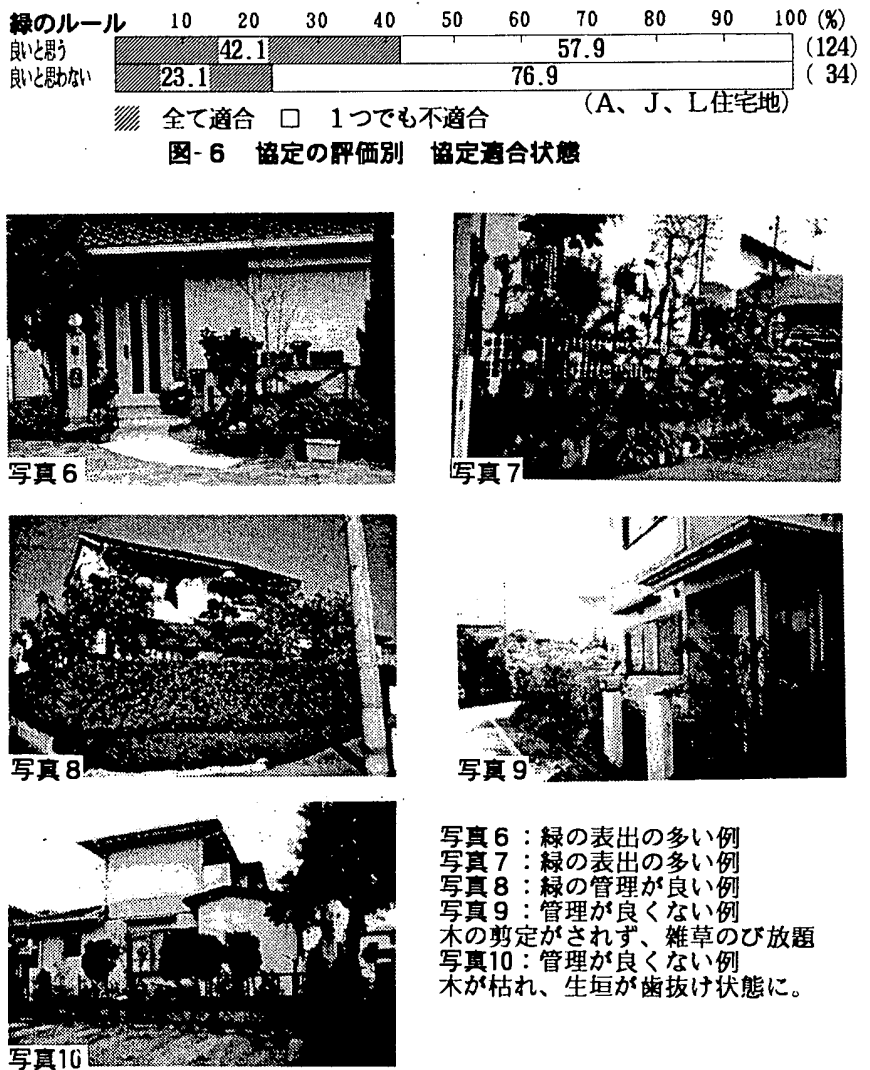

军萁6 : 粶の表出の多い例 写悬 7 : 粶の表出の多い例 軍 8 : 椂の管理が良い偧 貫 9 : 管理方良くない例 军10:管理加良くない例

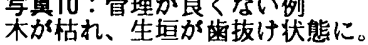

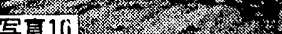

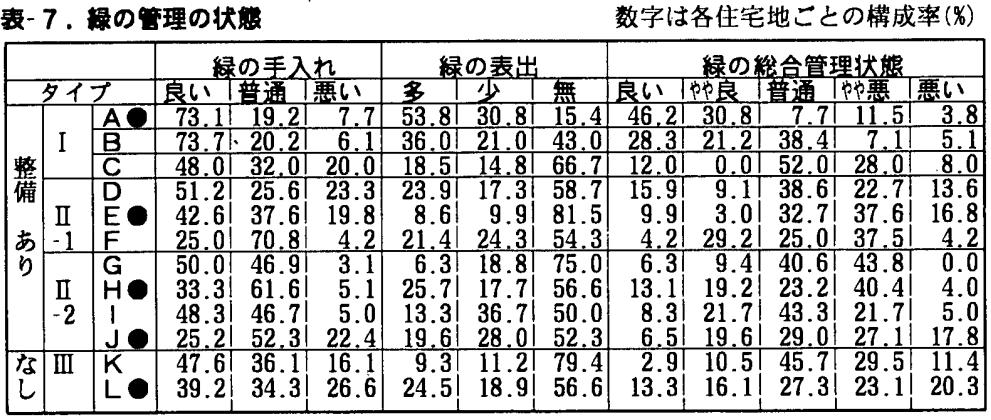

粶の手入れ；道路面からみた植栽(外構及び庭木)の手入れ・下草の手入れから 3 段階に

椂の表出 ; 評価しだーの量と美観性を考慮し、3段階に評価した。

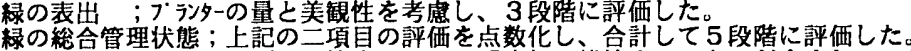

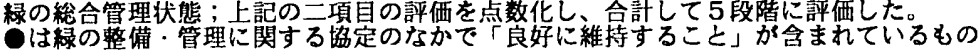




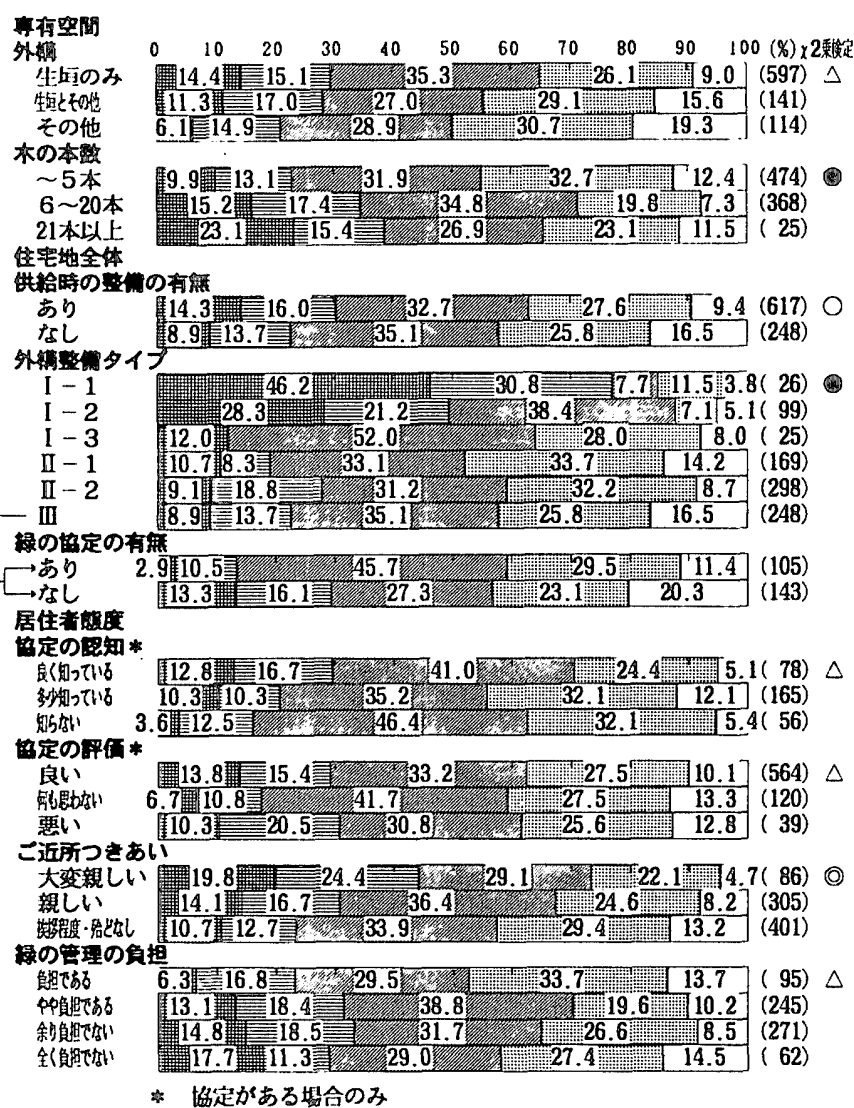

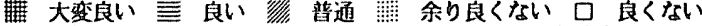

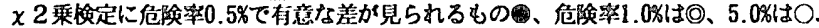

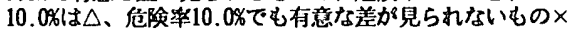

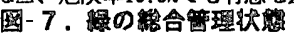

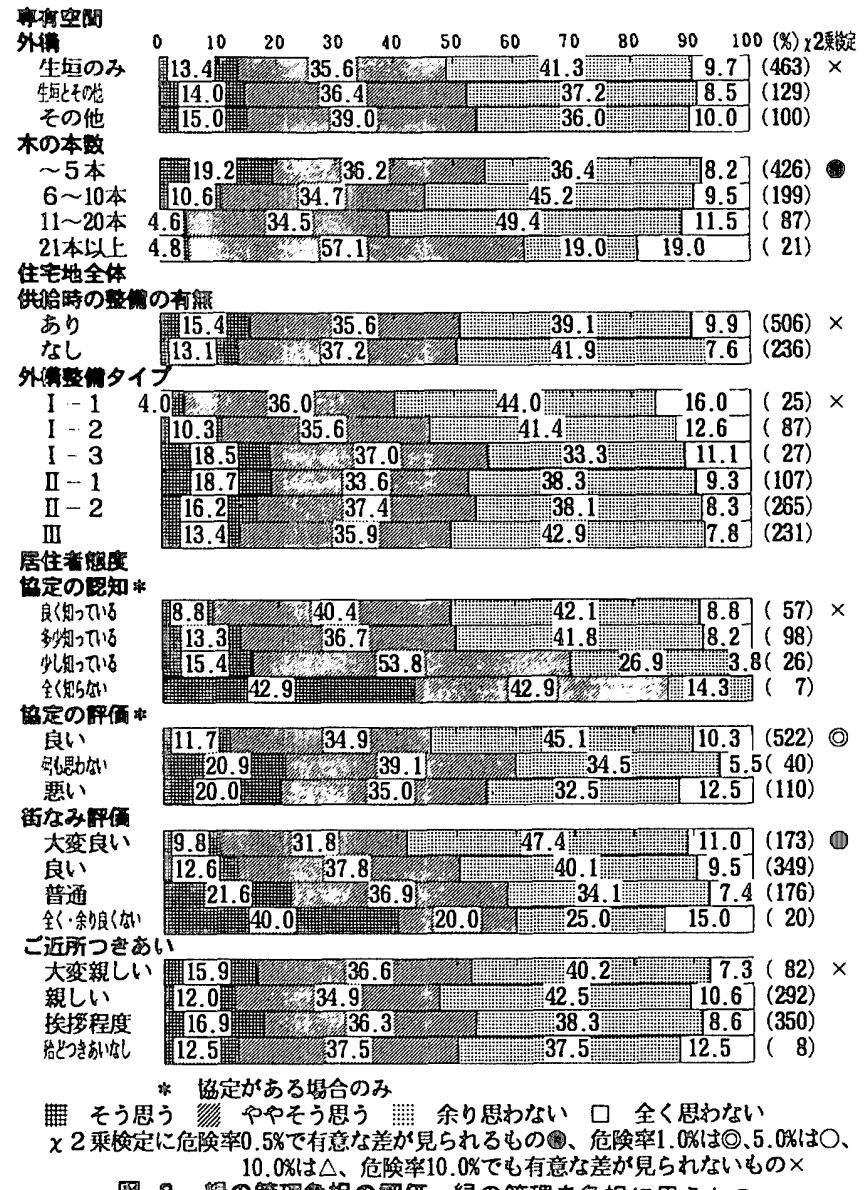

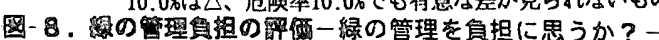

状態が巽なっている。そこで、どのような場合に㱍の管理を負担に 感じているかをみる。

各専有空間の粶の状態（庭木の量や外構が生垣か否か）による 「負担感」の相違をみると、外構が生垣か否かにより「負担感」の 相違はない。庭朴の量との関係をみると、庭不の少ない人の方がむ しろ「負担である」と回答している人が多い。

外䍘整備方法による違いをみると、供給時の整備の有無による違 いはみられない。つまり、居住者が自分自身で植樹したか否かと 「負担」意蛓は関係ない。

居住者の態度でみると、緑化協定を評価している場合、現在の自 分が住んでいる住宅地の街なみを評価している場合には「負担」に 感じる人が少ない。こ近所つきあいの状態による違いは明礁にみら れない。

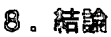

戸建て住宅地における居住者の専有品間の䩮による街なみ形成態 度とその規定要因をみてきた。以上の結果を図ー1に示した扳説に 照しあわせてみると以下のようになる（結果を図ー9に示す）。 (1). 街なみ形成に影翠を与える専有空間の䜌である外棈は供給方法 として外構整備方法による影整が大きい。

(2). 供給時に外構整備された住宅地では街なるに統一感があり、居 住者の詳価が高い。しかしどのような場合でも評価が高いわけでは ない。当初より街なみ形成を意図し、積極的に外構部分に緑を多く 整備した場合に居住者の婹価が高い。

(3). 居住者が粶を良好に管理していこうという態度は、外棘整備夕 イプ、こ近所とのコミュニティ形成の状態、そして管理ルールの認 知や俨侕、管理の負担㟲により規定される。

(4). 管理の負担感は街なみ俨価、緑の管理のルールの評価により異 なる。つまり、街なみを評価している人、その街なみを守るルール を評洒している人は、街なみを满成している緑を守り・育てたいと いう意向と理解があり、管理をあまり負担に思っていない。

(5)。粶の管理方法として、绿地協定などのルールは外满の生垣化や

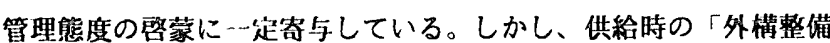
方法」は入居後の緑の整備状態を規定し、それにより街なみ評価が

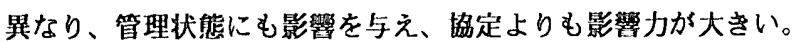

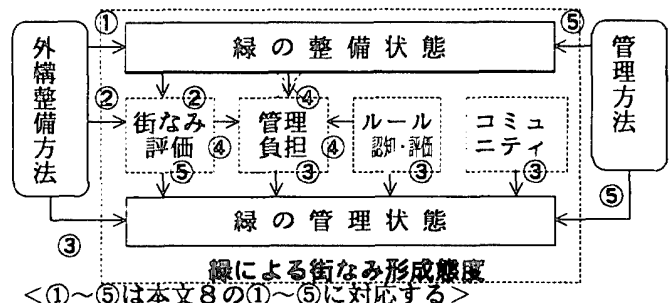

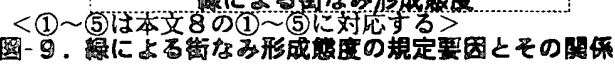

(6). 以上より計画的弪建て住宅地において、供給時から緑を整備す ることにより街なみの初期設资を居住者に示すことになり、居住者 の街なみ形成熊度を促進している。一方、協定はそのような状管を

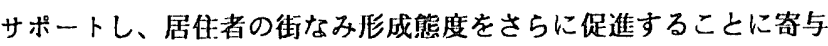
するか、「規制」よりも「脬導」的沿割を果たしている。しかし、 居住者に目標のイメージを提示していないところでは十分に有効に 
機能していない。居住者のコミュニティ形成は、近陆と街なみへの 慮を高めており、街なみ形成熊度に寄与している。

(7). 今後年数が経過すれば增改筑・改善の必要性が高まり、また入 居者の入れ替わりが激しくなることから街なみが崩れていく可能性 が高まる。そうなると供給当初に示された街なみといった目骠のイ メージを共有しにくくなる。そのような状沇では、管理方法として 現状のような㙝定といった「規制」力はほとんど倒かず、「抽象的 な啓蒙」としてのルールだけでは十分に対応していけなくなること が考えられる。そこで居住者のコミュニティをいかした共同管理、 つまり目標や手段の共有化を行うことでこれらの䦗題を予防・解消 していくことが必要となってくる。具体的には、生垣の共同管理之 して、生垣の整借や管理のガイドラインやマニュアルの作成、植栽 組合の結成、生垣の剪定や手入れの共同発注などがあるが、どのよ うな方法が有効であるかは、今後の倹討課題である。

謝辞：本研究を進めるにあたり、調査には川瀨明美・魹山達子・三

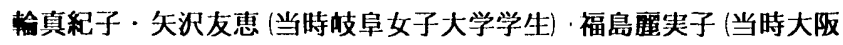
市立大学大学院生)の協力を得た。ここに記して感謝の意を表す。

\section{補注}

1)戸建て住宅地のおいて街なみ形成の視点からみると供給の代方は 次の四つのタイプにわけることができ、街なみや景観、住噮境形 成を意図し、緑による外構を整備し供給する(2)～(4)のタイプが最 近增玑している（参考文献 1 ）。

(1)外構整備も行わず供給（街なみ形成のための特に工夫なし）。 (2)外構整備のみを行う。

(3)道路形態など公有空間を工゙夫し、外粠整備を行う。

(4)道路形態などを工夫し、コモンスペース(共有架間)をつくり、 外構整借を行う。

2「整備」という言集のなかに「管理」が含まれることがあるか、、 本研究では「計画」に基づいて植樹されたものがいかに管理」 されているか、その対応関係を明らかにすることを目的としてい るため、「整備」のなかに「管理」を含めず、「整備」という言 葉を狭義で用いる。

3)緑の管理の状態は街なみに与える影響が大きい（参考文献 6）。 4)一部戸建て住宅地においてコーポラティブ方式で居住者が整備過 程に参加している事例もある(参考文献 2)。

5) 参考文献 3〜 5なと

6）協定があることで生垣化が進んでいる（参考文献 4 ・5など）。 7)協定があることで生垣化が進み、その管理の良好化が進んでいる （参考文献 4 ・ 5 など）。

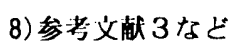

9)管理埩担感は厓住者の属性による相逢も考えられるが、ここでは 緑の整備・管理手法を考察することを目的としていることから、 それらの相違による偩担感の相違を明らかにする。

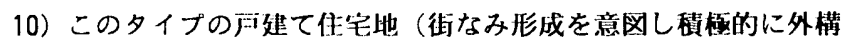
に緑か整備されたう建て作宅地）を把握するために、タイプの異 なる建築・住笔に罒する雑詰（日経アーキテクチュア・日経BP 社の1984.1号〜1997.7塄、新建築・新建築社の1977.1号〜1997.7 !’、ハウシンクトレンド・大阪ガスの1986.10号〜1997.7号）で
緑の整備手法と具体的な住宅地名を把握した。

11）都市緑地保全法の改正により緑地協定に名称が変更になったか、、 各住宅地では緑化協定という名称で使われているため、ここでも 緑化協定という名称を用いる。

12）戸建て住宅地において緑の量を示すものとして、(1)接道部緑化 （生垣、道路境界線近くの中高木の量）、(2)庭木の量、(3)通りか ら木が建物を覆うレベルなどがあるか、本論文では簡㳊でかつ居 住者からみた身近な緑の指標として主に外構の状䈍に注目し、外 構か「生垣」か否か、そして手入れに関しては庭木の「中高木の 本数」をあわせて緑の整備指僄之した。

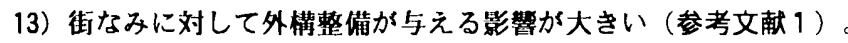

14）外部観察調查を実施する前に、調查対象住宅地で街なみ形成に 奇与する態度とそうでない態度を把握した。そのなかで緑の管理 に関する態度として二つの態度を把握し、これらを粶の管理状熊 を示す指標とした。

15）緑の総合管理熊度は緑の手入れ、緑の表出を 3 段階に評価し、 それらを得点化し合計点を求め、5段橗に分けた。

\section{参考·弓用文献}

1）齊藤広子：戸建て住宅地の評価 家とまちなみ35号 P.39〜51 （財）住宅生産振興財団 1997

2）齊藤広子他：接地型コーポラティブ住宅地の計画之管理への居 住者参加 日本建築学会東海支部研究報告書 P.793 796 1996

3）丸田頼一・島田正文他：市街地における緑化推進施策に関する 研究一千㷊市における緑化協定の現状と課題一 第22回日本都市 計画学会学術研究論文集 P. 37 P.42 1987

4）坂本磐雄・山口紘他：緑化協定制度による戸建て住宅地生垣化 奻果に関する研究 第25回日本都市計画学会学術研㶢論文集 P. 241 P. $246 \quad 1990$

5）田中正美・坂本磐雄・山口紘他：建築協定制度による戸建て住 宅地接道部緑化の可能性に関する研究 第27回日本都市計画学会 学術研究論文集 P.121 P.126 1992

6）齊藤広子：戸建て住宅地の住赫境管理からみた街なみ形成の要 糸とそのルールづくりに関する研究 1995年度第30回日本都市計 画学会学術諭文集 P.343 348 1995

7）齊藤広子：戸建て住宅地における住㬓境管理ルールとしてみた 地区計画之建築協定についての居住者の評価 日本建築学会論文 集第513号 P. 205 212 1998

（1999年 3 月 9 日原稿受理，1999年 8 月16日採用決定） 